\title{
Truth, Generalizations, and Stigmas: An Analysis of the Media's Coverage of Morris Brown College and Black Colleges Overall
}

Marybeth Gasman

University of Pennsylvania, mgasman@gse.upenn.edu

Follow this and additional works at: https://repository.upenn.edu/gse_pubs

\section{Recommended Citation}

Gasman, M. (2007). Truth, Generalizations, and Stigmas: An Analysis of the Media's Coverage of Morris Brown College and Black Colleges Overall. Retrieved from https://repository.upenn.edu/gse_pubs/196

Truth, Generalizations, and Stigmas: An Analysis of the Media's Coverage of Morris Brown College and Black Colleges Overall by Gasman, Marybeth The Review of Black Political Economy, vol. 34, no. 1-2, pp. 111-147, June 2007

The original publication is available at www.springerlink.com, DOI: 10.1007/s12114-007-9001-z

This paper is posted at ScholarlyCommons. https://repository.upenn.edu/gse_pubs/196

For more information, please contact repository@pobox.upenn.edu. 


\title{
Truth, Generalizations, and Stigmas: An Analysis of the Media's Coverage of Morris Brown College and Black Colleges Overall
}

\author{
Abstract \\ A content analysis of the media's coverage of Morris Brown College's situation suggests that the media \\ have made and continues to make generalizations about Black colleges based on the faults of a few. \\ These generalizations call into question the very existence of Black colleges. Although news reports \\ began with appropriate questions about the leadership, financial stability, fundraising ability, and quality of \\ the board of trustees at Morris Brown, they quite frequently attributed the institution's problems to Black \\ colleges as a whole.
}

\section{Comments}

Truth, Generalizations, and Stigmas: An Analysis of the Media's Coverage of Morris Brown College and Black Colleges Overall by Gasman, Marybeth The Review of Black Political Economy, vol. 34, no. 1-2, pp. 111-147, June 2007

The original publication is available at www.springerlink.com, DOI: 10.1007/s12114-007-9001-z 


\title{
TRUTH, GENERALIZATIONS, AND STIGMAS: AN ANALYSIS OF THE MEDIA'S COVERAGE OF MORRIS BROWN COLLEGE AND BLACK COLLEGES OVERALL
}

\author{
Marybeth Gasman
}

\begin{abstract}
A half-century after Brown v. Board of Education, 40 years after Lyndon Johnson's speech endorsing the concept of affirmative action, and two years after the Supreme Court upheld racial diversity as a factor in admissions, the approximately 80 historically black colleges and universities still enroll more than 10 percent of the African-American students in higher education and award close to 20 percent of degrees. These institutions have produced leaders from Thurgood Marshall to Jesse Jackson to Spike Lee. Their step shows, marching bands, and fraternities and sororities have become integral elements of African American culture. It is [common] in black churches and neighborhoods for parents to believe that their children will have better outcomes in black colleges than in mostly white ones, because the black schools provided a more nurturing, supportive environment, free of white presumptions that blacks are intellectual inferiors or expectations they should portray the role of hiphop gangsta. But what happens when the truism appears less and less true? What happens when an education emergency is ignored except by those enduring it? (Freedman, August 3, 2004).
\end{abstract}

The above quote about the dire situation at the nation's Black colleges was penned by New York Times reporter Samuel Freedman and is based on his visit to one historically Black institution-Texas Southern University (TSU). In fact, one of the individuals interviewed for the article by Freedman, scholar Jacqueline Fleming, was angered enough by the reporter's comments and interpretations to write a letter to the editor of the Times. In the words of Fleming, a faculty member and Director of the General University Academic Center at TSU,

I cannot say how disappointed I was with the article by Samuel Friedman [sic] on black colleges. ... I do understand his assignment was to inves- 
tigate low graduation rates, but that is where the problem begins. His assignment could have just as easily been to find out why TSU's one-year retention rates (the first step in graduation rates) has increased each year since 1997, even while the average test scores of incoming students have declined over this same period (August 16, 2005).

In her criticism of Freedman, Fleming alluded to what can be seen as a larger problem in the way the media treats historically Black colleges. Fleming, the author of the classic book Blacks in College-one of the first comprehensive, longitudinal studies comparing the performance of African American students enrolled at Black colleges and historically White colleges, took Freedman to task for his approach in framing the article:

[T] his situation reminded me that when I published the major comparative study of Blacks in College in 1984, a New York Times Education reporter was taken with the research and outcomes for black colleges that were more positive than anyone would have expected at that time. (It is far better understood today that nurturance and the absence of prejudice promote intellectual development among black students.) I was told when to expect the story to appear, but it never did. Apparently at the 11th hour, the Editor canceled it. Could it have been that this story about black colleges was far too positive? Perhaps only a story on a black college crisis is worthy of print (August 16, 2005).

Of course, the recent New York Times story is not the first account to negatively portray Black colleges. As some of the nation's Black institutions have found themselves in dire financial straits-Morris Brown College, Bennett College, and Philander Smith College are a few examples-reporters covering happenings at these colleges have often painted the shortcomings with a broad brush, sometimes generalizing to include all Black colleges, both private and public. The claims of these news articles have gained national attention, jeopardizing recruitment efforts, fundraising success, and in some cases, the long-term existence of the institutions (Basinger, April 17, 2003; "Morris Brown loses appeal," April 8, 2003; Poe, November 14, 2002; Simmons, October 6, 2002; Williams, October 18, 2002). After reading these newspaper articles, I wanted to examine bias in the media's coverage of Black colleges on a larger scale.

Morris Brown College, in particular, provides a telling example. The small, private, church supported institution lost its accreditation, is \$27 million in debt, and has been accused by the federal government of misuse of financial aid funds. This paper reports the results of a content analysis I conducted of the 
media's coverage of recent events at Morris Brown College in Atlanta. Content analysis allowed me to examine a large mass of written material from a range of media venues. It gave me an indication of the dominant ideas being put forth by the media on the subject of Black higher education. Specifically, I was interested in the words and phrases used to describe both Morris Brown and other Black colleges mentioned in the articles. I noted the possible generalizations made about Black colleges as a result of Morris Brown's situation. In conducting this content analysis, I looked at local, regional, and national media outlets.

\section{REVIEW OF LITERATURE}

Throughout American history the media and higher education have had a lukewarm relationship. Conventional wisdom and scholarship suggest that higher education has only recently come under intense and sometimes unfair scrutiny by the media due to accountability questions and corporate scandals (Jones, 2004). According to this view, prior to the 1980s the press treated most postsecondary institutions with a hands-off attitude (Stepp, 2003; McLendon \& Peterson, 1999). In contrast, when one looks at the history of media coverage of Black colleges and universities, it appears that these institutions have been the recipient of countless jabs and continuing skepticism since their beginnings (Willie, 1978; Jones 2004).

In recent years, several scholars have explored the relationship between higher education and the media. Rochelle Stanfield (1998) examined the ways in which the media misleads the public with regard to tuition costs_claiming that costs are increasing at greater rates than is supported by national data. Michael McLendon and Marvin Peterson (1999) analyzed media stories pertaining to the 1995 state appropriations conflict between the University of Michigan and Michigan State University to examine the influence of the media on public policy. The authors discovered that the media had considerable influence over local and regional politics, shaping the public discourse and selectively reporting on the appropriations conflicts. When race was considered alongside higher education coverage, the results were quite interesting. For example, Jane Rhodes (1999) explored national press coverage of the Black Panther Party, finding that initially the national press had no interest in the group. However, once the organization gained momentum in cities and on college campuses, the media sharpened its portrayals of Black Panther ideologies-eventually elevating the Panthers to celebrity status. Perhaps the closest study to that undertaken here is Bruce A. Jones' (2004) study of 1980s Chronicle of Higher Education coverage of university scandals, including Black colleges and their historically White counterparts. Jones found that between 1980 
and 1989, there were 25 stories in the Chronicle on scandal and corruption. Many of these pertained to Black colleges. Unlike the treatment received by historically White institutions (usually a "slap on the hand" by the media), newspapers called for the closure of some Black institutions. Subsequently, state governments threatened to close some institutions. As a result, some Black college administrators began to claim that the media had a dual standard of treatment toward college and university scandals.

\section{CONCEPTUAL FRAMEWORK AND METHOD}

It is not a secret that the media is attracted to controversy; however, many reporters still maintain that they operate with the heightened sense of objectivity emphasized in journalism school. According to Cohen (1963) "the pattern of news coverage ... influences public perceptions of what current issues are important (p. 229). Cohen referred to these patterns as the 'media agenda' (Cohen, 1963; McCombs, 1992, McClendon and Peterson, 1999). Moreover, according to media scholar Iyengar (1988), "there can no longer be serious doubts over the ability of the mass media to influence the political agenda. The agenda-setting effect has proven to be quite robust, spanning a variety of issues, media channels, and target audiences" (Iyengar, 1988, p. 338). With the concept of "agenda setting" in mind, I examined the media's treatment of Morris Brown College during its recent accreditation and financial situation, looking at how the media might shape the public's understanding of the institution in both positive and negative ways. In addition, I examined the media's interpretation of the situation for Black colleges overall based on their understanding of Morris Brown.

There is no single definition of content analysis as a research method. Thus, to guide this project, I borrowed from several sources (Bishop, 2003; DeVaney, 1987; Fitsgerald, 2000; Gall, Borg, and Gall, 1996; Lincoln and Guba, 1985; Tuckman, 1978; Zelizer, 2002). However, my approach was primarily informed by David Altheide's Qualitative Media Analysis. In his book, Altheide describes a three-part process that calls for the identification of frames, themes, and discourses within the content of written material. Specifically, he notes: "Frames focus on what will be discussed and how it will be discussed. . .."; in other words, how the media selects the content for the article (Altheide, 1996, p. 31). According to Altheide, themes pertain to the recurring and dominant ideas that appear within the material that has been selected. Lastly, Altheide describes the discourse as the actual messages being communicated by the documents (in the case of this study the newspaper/website/television reports) - that is, the words, the images, photographs, phrases, etc. Thus, according to Altheide, the documents analyzed "carry the discourse that reflects 
certain themes, which in turn are held together and given meaning by a broad frame" (Altheide, 1996, p. 31).

To acquire data for this research project, I systematically collected newspaper and magazine articles, television transcripts, and web-based publications for a period of two years. In order to obtain wide reach, I subscribed to an internet news search service that finds all of the news stories published on Black colleges each day and sends a summary and corresponding internet link to my email address. In addition, I sifted through newspapers and magazines and conducted ten Lexis-Nexis searches covering the two-year period of Morris Brown's recent financial and accreditation struggle. These efforts yielded a total of 407 news stories pertaining to Morris Brown College and/or Black colleges in general. I did not include articles that were about individual Black colleges other than Morris Brown. The stories that I examined were found in Atlanta newspapers, regional and national papers, as well as trade papers and magazines such as The Chronicle of Higher Education and Black Issues in Higher Education. In acquiring articles from a multitude of sources, I aimed to get a sense of the treatment of Black colleges in a broad cross-section of media outlets. I read each of the articles carefully, identifying frames, themes, and discourse as described above. The resulting paper is divided into three sections according to Altheide's structure: Frames, which focuses on what the media discussed and how they discussed it; Themes, which highlights the dominant ideas that appear in the media's discussion; and Discourse, which emphasizes the way the media represents the issues at Morris Brown using descriptors and phrases.

\section{ORIGINS AND MISSION OF MORRIS BROWN COLLEGE}

In 1885, the State of Georgia issued a charter to Morris Brown College, an institution founded on the idea of serving students from low-income backgrounds. ${ }^{1}$ Unlike most other Black colleges, Morris Brown was started by African Americans, a fact that gave the institution few resources but greater autonomy. ${ }^{2}$ As members of the African Methodist Episcopal (AME) Church, the college founders were dedicated to providing an educational experience that was inclusive of Black students from diverse backgrounds. According to Morris Brown's own description, the "College not only has inspired average and better than average students to great heights of achievement in competition, but has also transformed sensitive 'high risk' students into performers far better than their credentials suggest them capable" (www.morrisbrown.edu, February 6,2004$)$. Although this is a noble cause, over the course of its lifetime, Morris Brown's dedication to low-income students (and hence to the receipt of fewer tuition dollars) has caused it many financial problems. The AME 
Church provides some institutional support but has not been able to give enough funding to offset these diminished revenues.

During the early 1990s, Morris Brown College faced a $\$ 10$ million deficit that caused students, faculty, alumni, and the local Atlanta community to question its future existence. However, the Morris Brown community refused to let the institution go under, raising \$7 million dollars in donations and saving $\$ 2$ million through cost-cutting strategies. Although still struggling financially during the latter part of the 1990s, the institution was able to deflect negative publicity, and even garnered some nationwide media coverage when thenpresident, Dolores E. Cross, announced that every first year student at Morris Brown College would be furnished with a laptop computer. Nonetheless, in the fall of 2002, the institution became mired in controversy once again. Its commitment to supporting low-income students combined with inappropriate spending and accreditation problems catapulted the small college into the national spotlight.

\section{FRAMING THE SITUATION AT MORRIS BROWN COLLEGE}

The media's framing of the problems at Morris Brown College manifested itself in the following questions: What are the financial problems at the institution? Will it maintain its accreditation? Who is leading the institution? And who is saving the institution? All of the media stories center on at least one of these questions and in some cases all of them. Although at first glance these frames seem quite typical for the media's coverage of higher education stories, when I looked more deeply at the questions asked within each of the frames a unique set of themes emerged.

The initial articles presented a discussion of the financial situation at the institution and tried to uncover, piece by piece, what was happening at the college, who was responsible, what changes were taking place, and what the ramifications of the financial situation were.

What Are the Financial Problems?

A November 2002 story on the Cable News Network (CNN) spelled out Morris Brown's financial quagmire bluntly and assigned blame directly in its "breaking news" story: "The historically Black college founded by former slaves is more than $\$ 23$ million in debt and could be forced to close in a crisis that is being blamed on its past president and her ambitious efforts to enlarge Morris Brown and raise its profile" (Haines, November 1, 2002, n. p.). The article gave an overview of each financial blunder made by the institution, sometimes assigning blame and sometimes not. Of note was the media's lack 
of attention to the college's financial plan for the future. The story included only one line about this plan: "The school is working on a recovery plan that could include tuition increases, job cuts and cutbacks in athletics and other programs" (Haines, November 1, 2002, n.p.). Another article of note, penned by the Associated Press, detailed the efforts being made by the new president of Morris Brown:

Charles Taylor, hired just three months ago, has been working to restructure the college's debt, which he put at \$23 million-a staggering amount for an institution with an endowment that stood at only $\$ 5$ million this summer. And he brought in an official from Howard University to shore up the troubled financial aid office, the root of many of Morris Brown's problems. The chairman of the board of trustees has also promised to reform the board by bringing on new members with business and financial backgrounds ("Morris Brown May Close," November 1, 2002, p. 1A).

This article had an almost hopeful tone in its depiction of the new president and his strategies.

The Associated Press's wire service also focused on financial problems but with an eye toward their effect on the individual student. Entitled "Morris Brown College May Close," the article began by describing the "mess" at the institution: "The financial mess at Morris Brown College is so bad that the cafeteria sometimes runs out of food, computer labs carefully ration paper and laptop computers that cost students $\$ 1,500$ each never arrived"(November 1, 2002, p. 1A). Another article in The Atlanta Journal-Constitution spoke to the financial frame in the title. Its title was "Catch-22 has Morris Brown in new bind; Pay up or lose funding, feds tell strapped school." The article gave a "play by play' of Morris Brown's financial woes and then turned to experts to discuss a way out of the financial situation (Simmons and Donsky, November 1, 2002, p. 1D).

Other articles were framed by the idea of financial instability but specifically addressed the role of federal agencies in investigating Morris Brown's financial situation. These articles detailed the federal "crackdown" on the college, widening the scope of the problems from the local to the national (Simmons, September 29, 2002; "Feds may cut off funding, November 1, 2002). Of note is that the author of one of these articles also writes for Cox News Service and thus the stories were nationally syndicated.

After Morris Brown lost its accreditation, the news stories were still financially framed but focused on how the institution would "rebuild" in their "debtridden" state. Reporters spoke of dropping enrollments. Those members of the Morris Brown community who were interviewed talked of "eliminating short-term debt, and paying off long-term debt" (Basinger, October 19, 2003, 
p. 1). Still other articles focused on how the beleaguered institution would prepare for the huge reductions in the enrollment-reductions that resulted from their loss of accreditation and in turn, loss of financial aid packages for students ("Morris Brown prepares for reduced enrollments, July 29, 2003; Hoff, September 25, 2003; Rowe, April 11,,2003). The last area of emphasis is that of program and staff cuts. Many articles focused on how the financiallystrapped institution was "making ends meet." For example, Sports Illustrated ran a story examining the suspension of the College's athletic programs and the resulting layoffs and upset students. Likewise, The Atlanta Journal-Constitution covered Morris Brown's struggles to collect outstanding student balances (in some cases the institution was forced to withhold diplomas, transcripts, and deny participation in graduation ceremonies) ("Morris Brown College Drops Athletics, May 6, 2003; Simmons, March 7, 2003).

\section{Will Morris Brown Maintain Its Accreditation?}

Although accreditation may not seem to be directly linked to an institution's financial stability; an institution is more likely to be held under the microscope if its financial situation is shaky. According to the Southern Association for Colleges and Schools (SACS), "The institutions [must] have a sound financial base and demonstrated financial stability and adequate physical resources to support the mission of the institution and the scope of its programs and services" (Principles of Accreditation, 2004). The organization goes on to describe the specific financial statements required as evidence of financial stability. Thus, according to SACS' principles, an institution's inability to manage its finances implies an inability to support its programs and provide adequate faculty and student services. In a looping set of circumstances, loss of accreditation by SACS leads to loss of financial aid dollars, leaving the institution even more unstable. Moreover, in the case of private Black colleges like Morris Brown, the denial of academic standing means a loss of membership in the United Negro College Fund (UNCF). The UNCF provided the institution with $\$ 24$ million over the past 10 years. Articles framed by accreditation focused on the details of Morris Brown's potential loss of accreditation and the possibility of regaining it.

Prior to SACS' decision to drop Morris Brown's accreditation, the media released story after story speculating as to whether or not the small college would maintain its academic standing. Each of these stories was tied to the financial problems at the institution. The Atlanta Journal-Constitution, for example, made a play on a popular African American-oriented movie with the headline, "Morris Brown Waits to Exhale." The article mentioned the accreditation briefly but also talked about the institution's enormous debt and meager 
endowment (Donsky and Jones, December 8, 2002). Likewise, The Chronicle of Higher Education published an article detailing the impending accreditation decision but the entire story was focused on the financial problems of Morris Brown and gave very little indication of what accreditation is and how it has an impact on a college (Williams, October 18, 2002).

Once Morris Brown lost its accreditation, the media focused on the impact of this decision on student financial situations. Most of the stories opened with news of the accreditation loss but quickly moved to the impact that this would have on Morris Brown students_-eighty percent of whom lost their financial aid. ABC News, for example, used testimonials by Morris Brown students: " 'I'm just going to have to go to another institution if this thing stands,' said Renata Robertson, who can't afford to stay if she doesn't receive half the $\$ 6,000$-a-semester tuition she gets in federal financial aid" ("Morris Brown College Faces Uncertainty," December 11, 2002). A Chronicle of Higher Education story included another student perspective on the accreditation situation:

'It's really breaking my heart to do this,' said Tiphanie Pharris, the reigning Miss Sophomore at Morris Brown. 'I believe you pledge your allegiance to one school, and that's where you stay.' But the uncertainty at Morris Brown - and the risk of losing a private scholarship that can only be awarded to students at accredited colleges-prompted Ms. Pharris and her mother to discuss a possible transfer to Clark Atlanta throughout the early part of this academic year (Williams, December 13, 2002).

The last group of accreditation-related articles pertained to how Morris Brown planned on regaining its status with SACS. These articles highlighted the institutions efforts to pay off debt. One strategy described in a story in Black Issues in Higher Education, called for the college to pay off its short-term debt in order to regain its accreditation. Specifically, the magazine reported,

Morris Brown has raised more than half of the $\$ 10$ million short-term debt that it owes, has maintained current notes on the long-term debt, and has restructured the board to recruit business and corporate leaders including two bank presidents. Many internal protocols have been improved and systems of accountability are being reviewed and strengthened ("Morris Brown to Begin Process, April 24, 2003, p. 8).

Who Is Leading the Institution?

Although this frame is not used as often the financial and accreditation frames, it is the underlying idea of multiple articles. At the outset of Morris 
Brown's publicized problems, the institution chose a new president, Charles E. Taylor, a veteran educator and businessman. He had served as president of Wilberforce University in Ohio from 1976-1984 and in a senior management position with British Petroleum Company. Taylor was seen as someone who was going to go into the institution and fix it-including the college's shortterm debt. The media portrayed him as an individual who was willing and had the courage to "turn the institution around" ("Morris Brown College Names Charles Taylor," October 14, 2002; "Morris Brown names educator," September 13, 2002; Donsky, September 13, 2002; Ghezzi, October 1, 2002).

As Morris Brown's troubles deepened, the media looked to Charles Taylor for leadership or the "final" word on the College's controversy and many of the articles focused on his approach to changing the institution. Typically Taylor's comments would be juxtaposed with more pessimistic statements about the school's future. For example, in an Atlanta Journal-Constitution article, Taylor's defense of the college is juxtaposed with a statement of doubt about the school's enrollment figures:

The school has already seen its enrollment decrease from 2,547 in the fall to an estimated 1,130 [April 8, 2003]. But Taylor insisted that the school will survive. 'Morris Brown will continue to improve, we will continue to raise funds and we will continue to meet the needs of our students,' he said. 'In time, we will also regain the college's accreditation' (Jones, April 8, 2003).

Not all of the media stories related to leadership focused on the president, however. Several pertained to the rejuvenation of the college's Board of Trustees. One article opened up with the statement, "Morris Brown College's board of trustees must be reorganized if the school is to recover from the worst financial crisis in its history, the board chairman says" (Donsky, October 24, 2002, p. 1F). This article and several others talked about the need to bring "new blood" into the institution so as to provide the necessary leadership ("Jackson expected to join Morris Brown," December 4, 2003). For years, members of the Atlanta community, both Black and White, have criticized the small college for the heavy representation of ministers on its Board of Trustees. These critics believed it would be more effective to have individuals associated with corporations on the Board.

At the climax of the Morris Brown controversy, just eight days after SACS rejected the College's appeal for re-accreditation, the president of the institution resigned. Framed using leadership, the articles in the subsequent days focused on why the president resigned and who would lead the institution in the future. BlackVoices.com, The Chronicle of Higher Education, The Atlanta 
Journal-Constitution, and many other news venues ran stories about the resignation, each beginning with the sense of loss felt by the institution ("Morris Brown President Quits," April 17, 2003; Basinger, April 17, 2003; Jones, April 16, 2003; "Morris Brown Trustees," May 8, 2003; Post, April 17, 2003; "President of Morris Brown College," April 16, 2003; "Morris Brown President Resigns," April 16, 2003). However, the media outlets quickly turned their attention to the story behind the resignation, looking for clues as to why President Charles Taylor left the college during its time of need. According to BlackVoices.com (a subsidiary of the Chicago Tribune), "things apparently went sour between Taylor and the board following the news April 7 that the school's accreditation bid was denied. Also Taylor had been criticized by many, including officials of the African Methodist Episcopal Church, for not publicly putting forth a comprehensive financial recovery plan" ("Morris Brown President Quits," April 17, 2003). Likewise, The Atlanta Journal-Constitution scrutinized Taylor's leadership, noting the ways in which he failed: "When he took office in September, Taylor promised students he would fix massive problems in the financial aid office or quit. While he reorganized staff positions and launched a fund-raising initiative, Taylor never publicly presented a comprehensive financial recovery plan" (Jones, April 16, 2003). This article appeared just seven months after the same paper lauded President Taylor's strengths and potential for achievement. Moreover, this paper failed to give any coverage to Taylor's financial plan for the college.

\section{Who Is Saving the Institution?}

Many articles were framed using the question, "Who is saving the institution?" Most of these tended to focus on the financial rescue of Morris Brown College. It is interesting to note that the media highlighted African American agency when using this frame; however, in doing so they also held Blacks responsible for the problems and future livelihood of the institution. According to NBC News and The Atlanta Journal-Constitution, the alumni were rallying together to support Morris Brown both in spirit and financially. In news stories filled with quotes by prominent Atlanta politicians, many of whom graduated from the small Black college, the media told of the swell of alumni support: "pledging $\$ 2.5$ million to help pull the school out of debt" and raising "\$50 million over the next year" (Simmons, October 26, 2002). Another story examined the Morris Brown students' efforts to raise money for the institution: "The students started the fund-raiser around 8 A.M. and by 3 P.M. collected around $\$ 2,000$ that will be given to Morris Brown ..." (Jones, March 9, 2003).

A few articles pertained to how the larger Black community was saving the institution, specifically the United Negro College Fund, prominent African 
American celebrities, the AME church and other Black colleges. Several media outlets focused on the generous support of the UNCF, of which Morris Brown was a member until it lost its accreditation. The UNCF took a vote from its 39 member colleges and decided to help "alleviate financial problems at the historically Black Atlanta school. .." ("Morris Brown Receives Funding," March 7, 2003).

Radio personality Tom Joyner was also identified as one who might save the institution when he offered " $\$ 1$ million through his private foundation to help current students at Morris Brown College complete their education" ("Joyner offers donation," August 20, 2003). The Atlanta Journal-Constitution ran a story about the College's close relationship with the AME church. The article, however, mainly offered a history of the relationship and neglected to talk about the current support it offers Morris Brown (Jones, December 11, 2002). Questions of whether or not an organization should take part in "saving" the college were vetted by many Black colleges. Howard University, specifically, devoted several pages of its Hilltop to the subject of preserving the Atlanta college. According to its president, H. Patrick Swygert, "We are involved because Morris Brown is a sister institution with a great and important history and a bright future. We are involved because we at Howard take our leadership responsibilities seriously. This nation should be about the business of creating more not fewer higher education opportunities" (Hamilton, March 7, 2003, n.p.).

\section{COMMON THEMES IN THE MEDIA'S TREATMENT OF MORRIS BROWN COLLEGE}

Within the frames, which hold the media's portrayal of Morris Brown together, there are several dominant themes. These include: decline of Black colleges, desertion, failure, and devotion.

\section{Decline of Black Colleges}

One of the themes receiving the most attention from the media, and perhaps the most damaging to the future of Black colleges, is that of their decline. The theme most frequently appeared in articles framed by finance and accreditation. Quite often, the media generalized the experiences at Morris Brown and applied them to Black colleges overall. With one exception, the wider reaching, national stories about Morris Brown seemed to give the media an opportunity to wax eloquently about the problems faced by all of these institutions. Historically, this practice of projecting the problems of one institution on the 
whole lot is common when one exams the history of media coverage (and scholarly analysis for that matter). For example, USA Today, ran a story entitled "2 Black colleges may close doors: Problems at Grambling State, Morris Brown reflect trend." According to the author,

Supporters of the nation's 105 historically Black colleges and universities are watching closely to see what happens. Over the past 26 years, the number of Black students in all colleges increased almost $60 \%$ to 1.6 million. In that time, 12 Black schools closed, most because of money problems from decreasing enrollments and inadequate endowments. Many historically Black colleges have trouble competing for students, faculty and money at a time when they're facing greater competition for Black students and teachers. Major public and private schools are aggressively recruiting Black applicants. To some, the decreasing number of Black colleges means fewer places where Black students can find a nurturing academic environment. To others, it simply represents market forces at work. Some question whether all of the schools are still needed (Copeland, December 10, 2002, p. A3).

Likewise, $C N N$ noted in their comprehensive coverage of Black colleges: "The crisis at Morris Brown has put a spotlight on the United States' 103 historically Black colleges, some of which are struggling as they compete with other schools for students, faculty, and funds" ("Black colleges suffer, March 17, 2003).

In an article that aimed to show the diversity among Black colleges, Audrey Williams June of The Chronicle of Higher Education used the Morris Brown story to introduce the idea of a mounting debate that "could shape the future of historically Black colleges nationwide" (Williams, January 17, 2003). The article addressed the current economic problems at all institutions, noting that these times have been particularly difficult for small Black colleges. Moreover, June claimed that "some supporters of historically Black institutions quietly question how much longer the weakest of the group can survive-and ultimately, whether they should. They say that many advocates for Black colleges are reluctant to take an honest look at some of the institutions where enrollment has dried up and cash is scarce" (Williams, January 17, 2003).

The Chicago Tribune also began its coverage of the nation's Black colleges by speaking to the diversity among these institutions. However, within a few paragraphs the article shifted its focus to their problems: "What happened at Morris Brown is tragic but not unique. Across America, many of the 103 historically Black colleges and universities are struggling to stay afloat, includ- 
ing some state-run institutions" (Glanton, October 21, 2002). The reporter continued by discussing the dismal state of affairs at Black colleges:

Many Black Colleges are suffering from decades of neglect, with crumbling infrastructures and antiquated facilities. They have few classrooms with computer terminals, inadequate science labs and few high-technology facilities. Conveniences that students on white campuses take for granted-email access, well-stocked libraries and inviting cafeteriasare rare at most Black Colleges (Glanton, October 21, 2002).

Of course, the reporter failed to mention that many historically White institutions are struggling financially and do not offer their students the "conveniences" provided by their wealthier counterparts.

The title of another article, "Private historically Black colleges under stress," implied that all such institutions are suffering." However, it gives only one example of a Black college "under stress" (Morris Brown) and in fact the expert interviewed in the article-James Rogers of SACS—says "The private colleges in our region, regardless of the nature of the institution [racial makeup], are the ones that are struggling the most. I don't see this as any sort of trend of the HBCUs" (Poe, December 11, 2002). Perhaps the most evenhanded national story on Black colleges, and the exception mentioned earlier, is that written by Michael Fletcher at the Washington Post. Fletcher titled his piece "At Black Colleges, Disparate Fortunes. One Atlanta School Thrives; Another Fails" - a title that reflects the complexity of the situation described. The article examines the problems faced by many Black colleges but through a wide range of interviews and hones in on the importance of these historic institutions. Fletcher commented:

Some are enjoying unprecedented prosperity, raking in record gifts and attracting increasing numbers of top-flight applicants. But others are confronted by financial and managerial problems, declining interest from prospective students and legal and legislative mandates that are forcing them to radically rethink their missions or even shed their Black identities (Fletcher, November 23, 2002, p. A01).

\section{Desertion/Allegiance}

Within the frames of accreditation and who would save Morris Brown, the theme of desertion/allegiance appears often. The main emphasis in this area is on students. Reporters spent time interviewing students and gauging the student response to Morris Brown's financial woes and loss of accreditation. The 
Savannah Morning News, for example, opened with "Morris Brown College promised to keep fighting after losing its accreditation this week, but many students at the historically Black school won't be around to see how things turn out. Those still on campus Tuesday said they were looking for another place to go to school next year, concluding that a diploma from an unaccredited college isn't worth the effort" (Niesse, April 9, 2003).

Likewise, The Atlanta Journal-Constitution interviewed disgruntled students who aimed to leave Morris Brown. According to one student who was trying to transfer to either Clark Atlanta University or Georgia State University, "I made a wrong choice when I came to Morris Brown. I'm suffering the repercussion of it. It's too bad it's gone this way. My senior year has just been a catastrophe" (Morgan in Simmons, November 7, 2002).

Students' decisions about whether or not to leave the institution were also the focal point of a Morris Brown related story in The Chronicle of Higher Education. The journalist detailed the conflicts that Morris Brown students were grappling with:

Although it is exam period at Morris Brown College, students here suddenly have quite a bit more to worry about than tests. Many of them say they'll be forced to spend their winter break trying to decide whether they will remain at the institution, now that it has lost its accreditation. "I just need to think," said a junior, Michele Thompson, as she headed to take a biology examination. "I don't know what I'm going to do. Who thought it would come to this? (Williams, December 13, 2002).

A key factor that most of the articles pointed to was the dedication of Morris Brown students to their school. This was expressed eloquently in a previously mentioned quote from The Chronicle of Higher Education, which described a student's attachment and loyalty to the Black college: “'It's really breaking my heart to do this,' said Tiphanie Pharris, a student mentioned earlier in this article. 'I believe you pledge your allegiance to one school, and that's where you stay" (Williams, December 13, 2002). Although the above-mentioned quotes are the words of students, the reporters chose which quotes to use, thus shaping the direction of the story. Reporters can look for the voices they want-voices that offer the perspective that fits their arguments.

\section{Failure}

Failure is a theme that is consistent in almost every article regardless of the frame. It either refers to Morris Brown's failure as a whole, the institution's former president Dolores Crosse's failure, the institution's failure to gain accred- 
itation or failure to win its accreditation appeal, the new president's failure, or the failure of Black colleges overall to manage and cope in the current economy. Initial articles about the Morris Brown situation discussed the institution's fiscal and academic failure. According to The Chronicle of Higher Education, for example, the "Southern Association of Colleges and Schools, the accreditation agency that put Morris Brown on probation 10 months ago because of its bad bookkeeping and lack of faculty members with advanced degrees, will determine the status of the college ..." (Williams, October 18, 2002). Likewise, in an article that all but predicts the failure of Morris Brown, Paul Donsky and Andrea Jones of The Atlanta Journal-Constitution wrote, "On Tuesday, the 117-year-old private Atlanta school will learn whether it will lose its accreditation - a potentially fatal blow that would cut off the federal financial aid most students depend on to help pay their college expenses" (Donsky and Jones, December 8, 2002).

In discussing the problems at Morris Brown, the media blamed the institution's former president Dolores Cross as well as some of the Morris Brown administration for poor decision making. Most articles alluded to misuse of financial aid funds and a poor decision to change the institution's NCAA status from Division II to I (forcing an increase in the institution's athletic budget from $\$ 2.2$ million to $\$ 4.3$ million). For example, The Atlanta Journal-Constitution placed the blame squarely with Cross:

In recent years, school officials took several steps to boost prestige and revenue that appear to have misfired. Former President Delores Cross, who resigned last February, built the school's enrollment from fewer than 2,000 students in 1998 to nearly 2,800 last year. To house the extra students, the college had to book rooms in Atlanta motels. That practice ended before this school year. In 2000, Morris Brown moved from NCAA Division II to Division I, the highest level of athletics. To compete in Division I, schools have to spend more money on scholarships and travel. ... The school also made headlines when Cross started a program to provide a laptop computer for each student-a first of its kind for a historically Black college. But the company that supplied the computers said Morris Brown never paid the $\$ 4.2$ million tab (Donsky and Jones, December 8, 2002).

Although many of the problems described by the paper have proved accurate, it is interesting to note that just two years earlier, the media, including the Atlanta Journal-Constitution and The Chronicle on Higher Education, were lauding President Cross for her groundbreaking thinking in the decision to require students to purchase the laptops. In this instance, the same frame- 
leadership — was being used, but the theme was innovation rather than failure. As with Delores Cross, the media labeled new President Charles Taylor a failure both during his appeal for re-accreditation and when he resigned from the institution. A Chronicle of Higher Education headline summed up the way Taylor's resignation was treated by the media: "President Resigns at Beleaguered Morris Brown College" (Basinger, April 17, 2003). Many newspapers said that Taylor had "no comprehensive plan" or "no recovery plan" for the institution and this is why he failed (Jones, April 16, 2003; Basinger, April 17, 2003). One article stated Taylor's problems this way: "during his brief presidency, he said little publicly about how he might turn the problems around to save the institution" (Basinger, April 17, 2003).

Devotion

Regardless of the frame used, in many of the articles on the Morris Brown situation, one theme rings clearer than any other-namely that a kind of religious devotion marks the college's culture. Of course this may be related to Morris Brown's strong church ties or its sense of spirituality and faith in the African American religious community; regardless, it is telling (and perhaps a reflection of the colleges location in the South) how often references to religion appear in the media's portrayal of the struggling Black institution. The Atlanta Journal-Constitution, for example, referred to a fundraising event for Morris Brown as such, "The ceremony at times felt like a church tent revival, with prayers, songs, and 'amens' shouted to comments from the podium" (Scott, March 16, 2003). Likewise, an NBC News story used language that compared the Morris Brown students to the Israelites fleeing Egypt—describing the "exodus" at the college and their "plight" (Hoff, September 25, 2003). The Florida Times-Union discussed the "faith" of the administrator, faculty and students: "A skeleton crew of faithful administrators, teachers, and students remain. They say they are devoted to restoring the reputation of the school known for educating anyone willing to work hard" (Basinger, October 19, 2003). In many ways, it appears that in the eyes of the media, the only thing that can save Morris Brown is prayer and "good old fashioned" hard work.

\section{DISCOURSE RESULTING FROM THE MEDIA'S COVERAGE OF MORRIS BROWN}

According to Altheide, the frames used by the media give meaning to specific themes and carry a discourse that becomes part of our everyday language depending upon our social and intellectual circles (Altheide, 1996). In the case of the media's coverage of the recent situation at Morris Brown College, the 
discourse is contained in "catch" phrases that are used continuously. Looked at as a whole, these phrases can be seen to indicate either the obsolescence or the uniqueness of Black colleges.

\section{Obsolescence}

Earlier I noted that the media contributes to the public's constant questioning of the future of Black colleges by attributing the problems of a few to allthus, establishing an agenda. Behind this is an assumption that Black colleges are obsolete-a leftover from times of legalized segregation (Thompson, 1973). The problems of Morris Brown, which are symptomatic of the obsolescence of these institutions, can be grouped into two larger categories. First, in the post-Brown era, integration makes Black colleges unnecessary. Consider the following examples:

Many other Black colleges have struggled to stay afloat over the last few decades as racial integration has altered enrollment, faculty, administrations and financial support at the schools (Poe, 2002).

Still, the question remains: In an era that's a generation removed from Jim Crow, how many private historically Black colleges and universities does the country need? (Poe, 2002).

It is time to face the facts: Morris Brown is among hundreds of financially weak historically Black colleges, most of which cannot survive another 20 years. Nor should they. They were born of a historic injustice-the vicious laws of segregation that kept African-American students, no matter how competent, out of historically white colleges and universities. With those laws long since repealed, scores of segregated colleges and universities are now looking for a new reason to exist (Tucker, 2002, p. 17A).

Although this discourse creates a bleak picture for Black colleges, it leaves a glimmer of hope in the possibility that these schools will indeed find a new "reason to exist."

Slightly more bleak is the notion found in many of the articles, that Black colleges, created in the days of slavery and segregation, bear the taint of inferiority. According to this perspective, this condition results in poor facilities, poor finances, low standards, and inadequately prepared students:

The college's situation speaks to a larger issue facing historically Black colleges. They need to be academically proficient, finically solvent and technologically sufficient (Post, April 24, 2003). 
The Achilles' heel for many historically Black colleges has always been incompetence in fiscal matters. The reasons are many and varied: hiring administrative support staff who are inadequately trained for their jobs; downright indifference on the part of personnel; and autocratic management structures instituted or perpetuated by college presidents who place a disproportionate emphasis on power and veneer (Willis, October 21, 2002).

Founded in 1885 by former slaves, the college has become a slave to debt that threatens to close its door ("The Morris Brown Mess, November 11, 2002).

The implication of these statements is that racism has led to the inferiority of Black colleges overall - and that these institutions have not been able to emerge from this second-class status (Thompson, 1973; Anderson, 1988; Brown and Lane, 2003).

\section{Uniqueness}

The second and more positive category of discourse on Morris Brown College points to the special role that it plays in the lives of African American students and the local community. One point mentioned in this discourse is that Morris Brown is a college founded by Blacks for Blacks-in fact, it is one a few Black colleges founded by a Black-controlled institution rather than northern White missionaries or philanthropists (Anderson, 1988). ${ }^{3}$ The following quotation, for example, nicely addresses not only these points, but also the college's special commitment to the needs of Black students: "With a mission to serve both high-achieving students and those 'who might not otherwise receive the opportunity to compete on the college level,' the school is the state's only college founded by Blacks" (Jones, December 11, 2002; "Morris Brown Trying to Collect," June 5, 2003). Another quotation from a Morris Brown student, included in The Atlanta Journal-Constitution, summarized Morris Brown's close connections to its student community: "This is my family now," he said. "I would never leave Morris Brown unless it loses accreditation" (Ghezzi, October 1, 2002).

Again, part of Morris Brown's uniqueness is the religious devotion of its community. This is made clear in a number of phrases used in the articles. Quoting an individual who was trying to raise funds on behalf of the struggling institution, one article stated: "We're doing everything we possibly can, and then we're going to pray" (Scott, March 16, 2003). Another article describes the fundraising effort as "passing the offering plate" (Simmons, October 27, 2002). And finally, referring to the Morris Brown's situation, another article 
quoted AME minister Michael Jones, who was invoking the college's motto: "Ain't nothing dead on Martin Luther King Drive. It's still a haven for hungry souls" (Simmons, October 27, 2002). The motto "haven for hungry souls" is indicative of the institution's close ties to the church.

\section{CONCLUSION}

On May 21, 2004, the Atlanta Journal-Constitution included an editorial entitled "Morris Brown must face financial reality and close." The following is an excerpt from the news story:

The 42 students who received degrees from Atlanta's Morris Brown College on Sunday should be commended for completing their studies amid the turmoil that has enveloped the college since it lost its accreditation in December 2002. In return for their hard work, however, they received degrees that will be questioned by prospective employers and graduate schools. They deserve better, as do the students who have chosen to remain at the financially troubled college. ... Morris Brown is on life support, and its leaders need to pull the plug. Morris Brown prides itself on offering a college education to students who might not otherwise have a change to attend a four-year school because of poor academic performance. They claim that these students would be the most vulnerable to an abrupt shutdown. Dozens of small colleges have the same mission, as do two-year and technical colleges. ... It's time to replace nostalgia with a reality check. Morris Brown officials have had years to correct poor management and massive debt. At this point, the best thing they can do is plan a graceful exit for the school and its students (editor, May 21, 2004).

Given Morris Brown's situation, a story this bleak might be unremarkableexcept that it is the culmination of two years of similarly dire articles about the institution. Moreover the discussion in these articles often spills over into Black colleges as a whole, with dire predictions for the lot of them. This leads this author to wonder how much influence the media has had over the outcome of Morris Brown's efforts to recover (not its problems). How much influence should it have?

Do the media have an agenda? Many alumni feel that they do. For example, alumna Clarisa Myrick-Harris writes,

I am told that the newspaper continues to publish its often-erroneous assessments because the editorial board is "concerned" about the welfare of the students. The paper's persistent meddling smacks of pater- 
nalism. Further, the paper's viewpoint is skewed and devoid of historical understanding about Morris Brown in particular and historically black colleges and universities in general (Myrick-Harris, May 21, 2004).

As Myrick-Harris notes, the media does not understand the mission of an institution like Morris Brown-one of racial uplift through access. Although community and technical colleges provide a kind of access, racial uplift in particular is not their mission-therefore, it is inaccurate to claim, as the Atlanta Journal-Constitution does, that Morris Brown could simply be replaced by these other institutions.

Of course, the media should act as a public critic, but should it direct our actions? Does the discourse produced by the media change the way the public views Morris Brown and, in effect, Black colleges? Although the media does not notice some of the good brought about by Black colleges, do they focus on these positives aspects of Black higher education less frequently? When we examine the coverage of the struggling institution over the course of a twoyear period, disturbing themes indicate a media agenda that springs into action whenever a historically Black college is in trouble. Morris Brown's critics may say that the institution made itself an easy target. Surely Morris Brown College deserved criticism. But one test of fair coverage is how it treats the worst cases. Does it confine criticism to the one at fault or allow it to taint the innocent as well.

A content analysis of the media's coverage of Morris Brown College's situation suggests that the media has made and continues to make generalizations about Black colleges based on the faults of a few. These generalizations call into question the very existence of Black colleges. Although news reports began with appropriate questions about the leadership, financial stability, fundraising ability, and quality of the board of trustees at Morris Brown, they quite frequently attributed the institution's problems to Black colleges as a whole. With very little background or knowledge of the history of these institutions, the media is contributing to a discourse on Black colleges, which contains catchphrases that are used continuously, picked up by politicians, policymakers, and academics, and thrust into the public domain. For example, the frame of financial problems at Morris Brown combined with the theme of the decline of Black colleges easily gave rise to a discourse on the "taint of inferiority" left over from segregation. This type of material is the source of the problem of media generalizations about Black colleges. Although the media has the full set of facts in front of them, they mold these facts into a form that results in a negative picture of Black colleges.

In its coverage, the media rightly pointed to the unique environment at Morris Brown College. However, they neglected to use this as an opportunity to 
show the diversity among Black colleges overall, and to point out that its situation is not representative of all of these institutions. Each Black college, although dedicated to racial uplift and the education of African Americans, has its own environment, culture, and struggles (Brown, 2003; Perna 2001). Black colleges themselves need to be aware of the types of discourse embedded in past media coverage and how this can distort their stories. They must expose examples of unfair coverage, thereby forcing the media to be responsible for understanding the history and culture of these institutions. Black college administrators and faculty need to keep track of institutional data and use it to counter stories pushed forth by the media. Overall, Black colleges need to be wise to the ways of the media and use an aggressive strategy. They must contribute to a national discourse on "their" institutions rather than letting the mainstream media set the agenda.

\section{NOTES}

1. Although the institution was established in 1881 , it did not receive a charter until 1885.

2. Due to the vestiges of slavery, African Americans did not have the resources to fund their own institutions, thus most Black colleges were funded by White missionaries, the federal government, and eventually northern industrial philanthropists. This fact severely hampered institutional autonomy.

3. The majority of Black colleges were founded by White northern missionaries and the Freedman's Bureau. During the late 1800s and early 1900s, White industrial philanthropists supported black colleges financially with the intention of controlling the future of black higher education.

\section{REFERENCES}

Altheide, D. (1996). Qualitative Media Analysis. Thousand Oaks, CA: Sage Publications. Anderson, James D. (1988). The Education of Blacks in the South, 1860-1935. Chapel Hill: The University of North Carolina.

Auditor questions college's ability to survive. The Associated Press, October 18, 2002.

Basinger, J. (April 17, 2003). President resigns at beleaguered Morris Brown College. The Chronicle of Higher Education.

Basinger, B. (Sunday, October 19, 2003). Morris Brown Ties to Rebuild. The Florida Times Union.

Bishop, R. (2003). The World's Nicest Grown-Up: A Fantasy Theme Analysis of News Media Coverage of Fred Rogers. Journal of Communication.

Black colleges suffer financial strain CNN, Monday, March 17, 2003, 9:59 A.M.

Brown, M. C. (Summer 2003). Emics and Etics of Researching Black Colleges: Applying Facts and Avoiding Fallacies, New Directions for Institutional Research, no. 118, 27-40.

Brown, M. C. and Lane, J.E. (Eds.). (2003). Studying Diverse Institutions: Contexts, Challenges, and Considerations. New Directions for Institutional Research. New Jersey: Wiley \& Sons.

Cohen, B. (1963). The Press and Foreign Policy. Princeton: Princeton University Press.

Copeland, L. (December 10, 2002). 2 Black colleges may close doors; Problems at Grambling State, Morris Brown reflect trend. USA Today, A03. 
DeVaney, A. (1987). Reader theories and educational media analysis. Paper presented at the Annual Convention of the Association for Educational Communications and Technology, Atlanta, Georgia.

Donsky, P. (September 13, 2002). Morris Brown chooses chief. The Atlanta JournalConstitution.

Donsky, P. (Sunday, December 8, 2003). Morris Brown to Learn its Fate Tuesday. The Atlanta Journal-Constitution.

Paul Donsky (October 24, 2002). Morris Brown seeks business-wise trustees. The Atlanta Journal-Constitution, 1F.

Donsky, P. and Jones, A. (Sunday, December 8, 2002). Morris Brown Waits to Exhale. Accreditation to be Decided. The Atlanta Journal-Constitution.

Donsky, P. and Jones, A. (December 8, 2002). Morris Brown accreditation to be decided. The Atlanta Journal-Constitution.

Editor (May 21, 2004). Morris Brown must face financial reality and close. Atlanta JournalConstitution.

Ex-Morris Brown president says bills paid with financial aid. The Associated Press. October 17, 2002.

Feds may cut off funding to Morris Brown. AccessNorthGA.com. Friday, November 1, 2002.

Fitzgerald, M. A. (200???). Criticizing Media: The Cognitive Process of Information Evaluation. Educational Media and Technology Yearbook. 25, 130-140.

Fleming, J. (August 16, 2005). Re: Little-Noticed Crisis at Black Colleges. Letter to the Editor of the New York Times (in possession of author).

Fletcher, M. A. (Saturday, November 23, 2002). At Black Colleges, Disparate Fortunes. One Atlanta School Thrives; Another Fails. The Washington Post, A01.

Freedman, Samuel G. (August 3, 2005). Little-Noticed Crisis at Black Colleges. New York Times, www.nytimes.com.

Gall, M., Borg, W., and Gall, J. (1996). Educational Research. New York: Longman.

Ghezzi, P. (October 1, 2002). School president: I'll fix it or quit. The Atlanta JournalConstitution, 1D.

Glanton, D. (October 21, 2002). Black Colleges Fight to Survive, Financial, other ills beset many venerable schools. The Chicago Tribune.

Haines, E. (November 1, 2002). Historically Black Morris Brown College in Trouble. CNN.

Hamilton, K. (March 7, 2003). Howard Committed to Saving Morris Brown. The Hilltop.

Harasin, L. (October 28, 2002). Morris Brown president to lay out recovery plan. Action News 2.

Hoff, V. (September 25, 2003). Morris Brown Opens with 70 Students News 11.

Iyengar, S. (1988). New directions for agenda setting research. In J. Anderson (Ed.), Communication Yearbook 11 (pp. 595-602). Thousand Oaks: Sage Publications.

Jackson expected to join Morris Brown's board of Trustees. The Macon Telegraph. December 4, 2003.

Jones, B. (2004). Toward strategic planning: Issues and status of Black colleges. In Brown, M. C. and Freeman, K. (2004). Black Colleges. Westport, CT: Ablex Press.

Jones, A. (April 8, 2003). Morris Brown won't close, president says. The Atlanta JournalConstitution.

Jones, A. (April 16, 2003). Morris Brown President Taylor Resigns. The Atlanta JournalConstitution.

Jones, A. (March 7, 2003). College fund gives \$1.5 million to school. The Atlanta JournalConstitution.

Jones, A. (December 11, 2002). College has kept close ties to church. The Atlanta JournalConstitution.

Jones, L. (March 9, 2003). Morris Brown Students Raise Cash. The Atlanta JournalConstitution. 
Joyner offers donation to Morris Brown. NBC News 11. August 20, 2003.

June, A. W. (October 18, 2002). Morris Brown College faces big debt and an accreditor's judgment. The Chronicle of Higher Education. 49, no. 8, A31.

June, A. W. (December 13, 2002). At Morris Brown College, Students Grapple With a Tough Decision: Stay or Go? The Chronicle of Higher Education.

June, A. W. (January 17, 2003). Endangered Institutions. Morris Brown's plight reflects the financial troubles of small, poorly financed Black colleges. The Chronicle of Higher Education.

Lincoln, Y. and Guba, E. (1985). Naturalistic Inquiry. Beverly Hills: Sage Publications.

McCombs (1993). The evolution of agenda setting research: Twenty-five years in the marketplace of ideas. Journal of Communication, 43(2), 68-67.

McLendon, M. \& Peterson, M. W. (1999). The press and state policy making for higher education, Review of Higher Education, 22, 3.

Morgan, D. quoted in Simmons, K. (November 7, 2002). Morris Brown students consider transferring out. The Atlanta Journal-Constitution.

Morris Brown College History, www.morrisbrown.edu [accessed February 6, 2004].

Morris Brown Receives Funding. NBC News 11. March 7, 2003.

Morris Brown prepares for reduced enrollment. The Associated Press. Tuesday, July 29, 2003.

Morris Brown Trustees Appoint Chemistry Professor as Acting President. Black Issues in Higher Education. May 8, 2003, 9.

Morris Brown College Names Charles Taylor its New President. JET. October 14, 2002.

Morris Brown names educator businessman as president. The Associated Press. September 13, 2002.

Morris Brown Trying to Collect Student Debt. Atlanta Daily World. June 5, 2003.

Morris Brown tries to collect student debt. Macon Telegraph. May 31, 2003.

Morris Brown President Resigns. NBC News. April 16, 2003.

Morris Brown President Quits. BlackVoices.com. April 17, 2003.

Morris Brown president lays out recovery plan. AccessNorthGA.com. October 28, 2002.

Morris Brown May Close. The Associated Press. November 1, 2002.

Morris Brown's financial aid practices investigated. The Associated Press. September 30, 2002.

Morris Brown to Begin Process of Re-Accreditation. Black Issues in Higher Education. April 24, 2003, p. 8.

Morris Brown College Faces Uncertainty. ABC News. December 11, 2002.

Morris Brown Alumni Raise 2.5 Million. NBC News 11. October 26, 2002.

Morris Brown College Drops Athletics. Sports Illustrated. Tuesday, May 6, 2003.

The Morris Brown Mess: The historically Black college is in debt and may close. Lee Bailey's Eurweb.com. November 11, 2002.

Myrick-Harris, C. (May 21, 2004). Morris Brown will overcome obstacles. The Atlanta Journal-Constitution.

Niesse, M. (April 9, 2003). Students leaving after Morris Brown loses accreditation bid. Savannah Morning News.

Perna, L. (2001). The contribution of historically Black colleges and universities to the preparation of African American faculty careers. Review of Higher Education, 42, 265-294.

Poe, J. (November 14, 2002). Black Colleges under Pressure to Change. The Atlanta Journal-Constitution. Front Page and F1.

Simmons, K. (October 6, 2002). Morris Brown at the brink. The Atlanta Journal-Constitution. Metro Section, C2, C4, C5.

Poe, J. (December 11, 2002). Private historically Black colleges under stress. The Atlanta Journal-Constitution.

Post, C. (April 17, 2003). Morris Brown President Resigns, Supporters Press On. Atlanta Daily World. 
Post, C. (April 24, 2003). Morris Brown President Resigns, Supporters press on. St. Louis American.

President of Morris Brown College Resigns. Tallahassee Democrat. April 16, 2003.

Principles of Accreditation, http://www.sacscoc.org/pdf/principle of accreditation1.pdf [March 9, 2004].

Rowe, S. (April 11, 2003). Deadline for Morris Brown Transfers. News 11.

Scott, P. (March 16, 2003). Morris Brown rejoices. The Atlanta Journal-Constitution.

Simmons, K. (April 8, 2003). Morris Brown loses appeal, may close as aid evaporates. The Atlanta Journal-Constitution.

Simmons, K. (October 28, 2002). Morris Brown at the Wall: Today may decide school's fate. The Atlanta Journal-Constitution.

Simmons, K. (October 5, 2002). Morris Brown: Laptop for every student is PR boon turned bust. The Atlanta Journal-Constitution. Metro Section, 5C.

Simmons, K. (March 7, 2003). Morris Brown wants pay before graduation. The Atlanta Journal-Constitution.

Simmons, K. (October 16, 2002). Morris Brown admits use of student aid to pay bills. Cox New Service.

Simmons, K. (September 29, 2002). Feds: Morris Brown Misused Student Aid. The Atlanta Journal-Constitution. 1A.

Simmons, K. (October 26, 2002). Alumni pledge cash for Morris Brown. The Atlanta Journal-Constitution.

Simmons, K. (October 27, 2002). Today may decide Morris Brown's fate. Cox Enterprises, Inc. Wire Service.

Simmons, K. and Donsky, P. (November 1, 2002). Catch-22 has Morris Brown in new bind; Pay up or lose funding, feds tell strapped school. The Atlanta Journal-Constitution, 1D.

Stepp, C.S. (January/February 2003). Higher examination, American Journalism Review.

Thompson, D. C. (1973). Private Black Colleges at the Crossroads. Westport, CT: Greenwood Press.

Tucker, C. (October 23, 2002). Morris Brown College: Ailing institution must face awful truth: It's time to close. The Atlanta Journal-Constitution, 17A (editorial).

Tuckman, G. (1978). Making News: A Study in the Construction of Reality. New York: Free Press.

UNCF to help fund Morris Brown College. Macon Telegraph. March 8, 2003.

Willie, C. (1978). Black colleges in America. New York: Teachers College Press.

Willis, G. (October 21, 2002). Rescue Black colleges from financial ruin. The Atlanta Journal-Constitution. Home Edition, 9A.

Zelizer, B. (2002) Journalists as Interpretive Communities. Critical Studies in Mass Communications, 10, 219-237. 
06_Gasman_9001_Trans 1/18/07 1:26 AM_Pagre 136
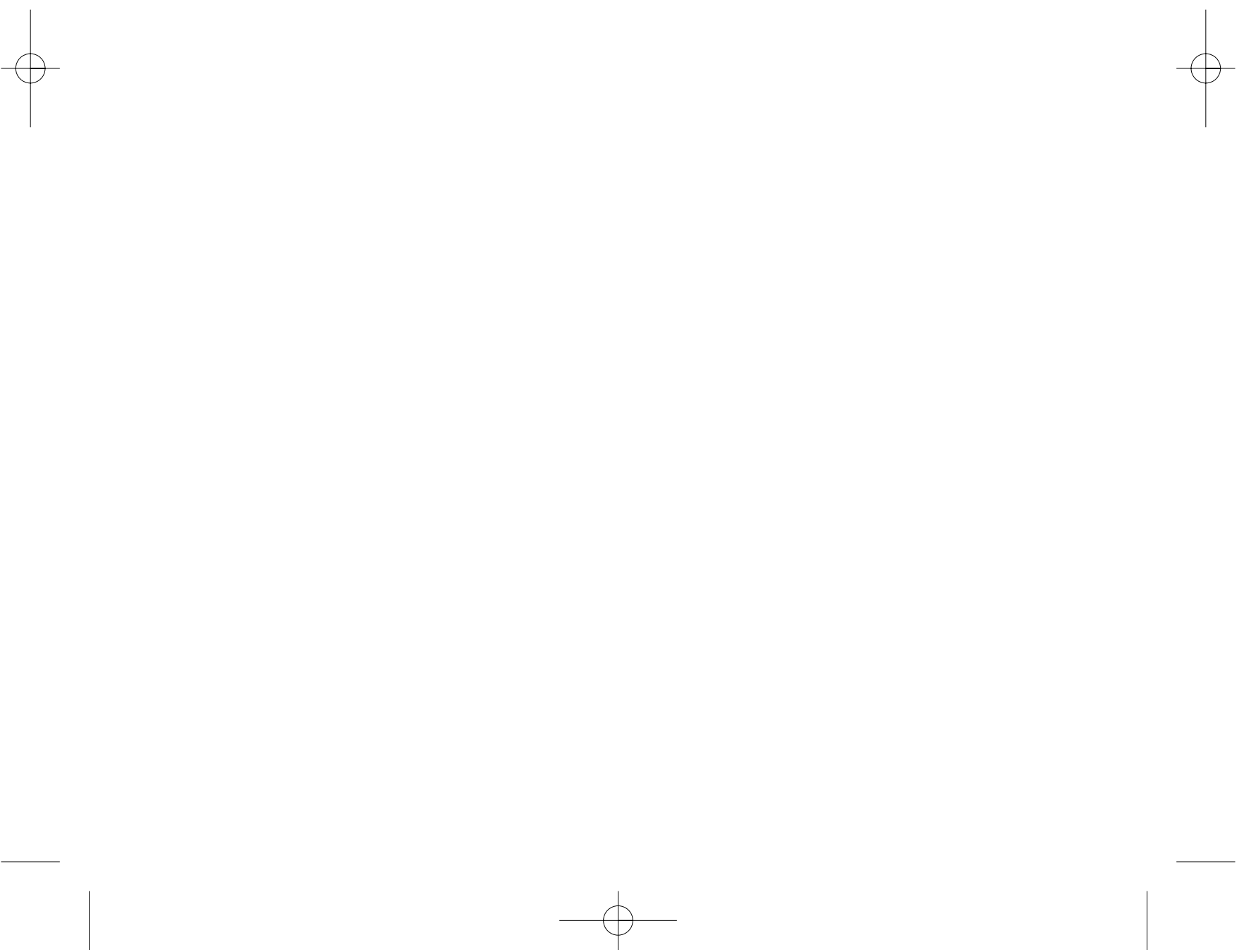